\title{
Integrating technology acceptance model and organizational innovativeness in the adoption of mobile commerce
}

\author{
Maruf Gbadebo Salimon $^{a^{*}}$, Jibril Adewale Bamgbade ${ }^{b}$, Ajulor Olusegun Nathaniel ${ }^{c}$ and Tijani \\ A. Adekunled
}

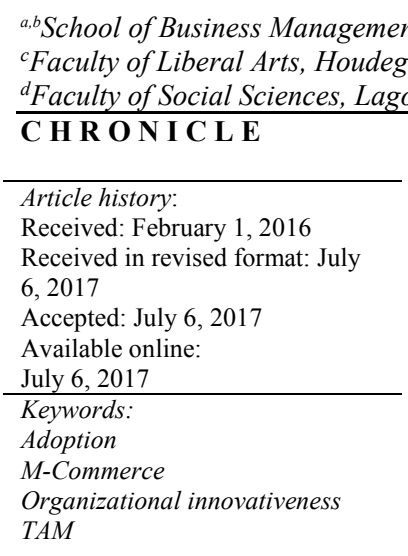

\section{Introduction}

The rate of competition in the contemporary business environment is getting higher. In order to survive in this tough terrain, organizations have started to improve the process through which products and services are delivered with the objectives of retaining their customers (Wei et al., 2009). The need to improve this process has also been warranted by the proliferation of internet technology that ushered in Mobile Commerce (m-Commerce) (Thakur \& Srivastava, 2013; Wei, et al., 2009). Today, m-commerce, which emanates from e-commerce has almost reached a climax in terms of the rate of adoption in Asia countries, while its acceptance in African nations seems to be lagging (Digital-Capital, 2014). Report from Digital-Capital (2014) reveals that Asian countries account for nearly half of the global m-commerce revenue, which stood at us $\$ 230$ billion, while sales revenue from m-Commerce in developing countries is still at very low ebb. It has also been advocated that despite the tremendous benefits which users of $\mathrm{m}$-Commerce can derive from its usage, the rate of adoption in a country like Nigeria is still low (Osakwe \& Okeke, 2016) as m-Commerce is still at the infant stage in developing countries

* Corresponding author

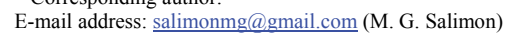


generally (Wei et al., 2009; Wong \& Hiew, 2005). For instance, experience has also indicated that many customers are still reluctant to accept this new technology notwithstanding that it has much potential in developing countries (United Nations, 2002). Despite the low rate of adoption of m-Commerce in developing countries, strong empirical evidence to validate this seems to be very scarce as most past studies were conducted in developed and emerging nations such as USA, China and Taiwan (Wei et al., 2009). In fact, majority of the previous studies based their concepts on traditional and original TAM (Davis et al., 1989) and other models such as theory of planned behavior (TPB) while the concept of organizational innovativeness which can improve the rate of adoption among customers has been ignored, completely. Recently, facts have begun to emerge that TAM is the most parsimonious model due to its simplicity and capacity in explaining over $40 \%$ adoption behavior of technology (Rana et al., 2013; Venkatesh et al., 2003; Yousafzai et al., 2010). However, series of studies have argued that except that TAM is extended by integrating other variables in line with the content and context of the study, its predictive capacity may reduce (Alalwan et al., 2016; Riquelme \& Rio, 2010; Shareef et al., 2014). In view of this, this study is extending original TAM by incorporating concept of organizational innovativeness as evidence has shown that apart from lack of usefulness and ease of use that constitute a barrier towards adoption of m-Commerce (Liao et al., 2007; Khalifa \& Shen, 2008; Wei \& Chong, 2009), lack of innovation among organizations offering the service is also an impediment to the rate of success of this technology based service. To the researchers' best knowledge, this study is the pioneer research that has extended TAM by incorporating the concept of organizational innovativeness to explain $\mathrm{m}$-Commerce adoption especially in developing countries. This is a major contribution to the body of knowledge as majority of previous mobile commerce studies have only considered customer innovativeness (e.g., Lam et al., 2008; Bhatti, 2015; Chong, 2013; Nysveen et al., 2005; Kam-Sing Wong, 2012), while organizational innovativeness has been totally ignored.

The remainder of the article proceeds as follows. The literature review and theoretical background based on the conceptual framework (Fig. 1) of this study are discussed in the next section. The third section introduced our research method while the conclusion and limitation of the study are discussed in the final part.

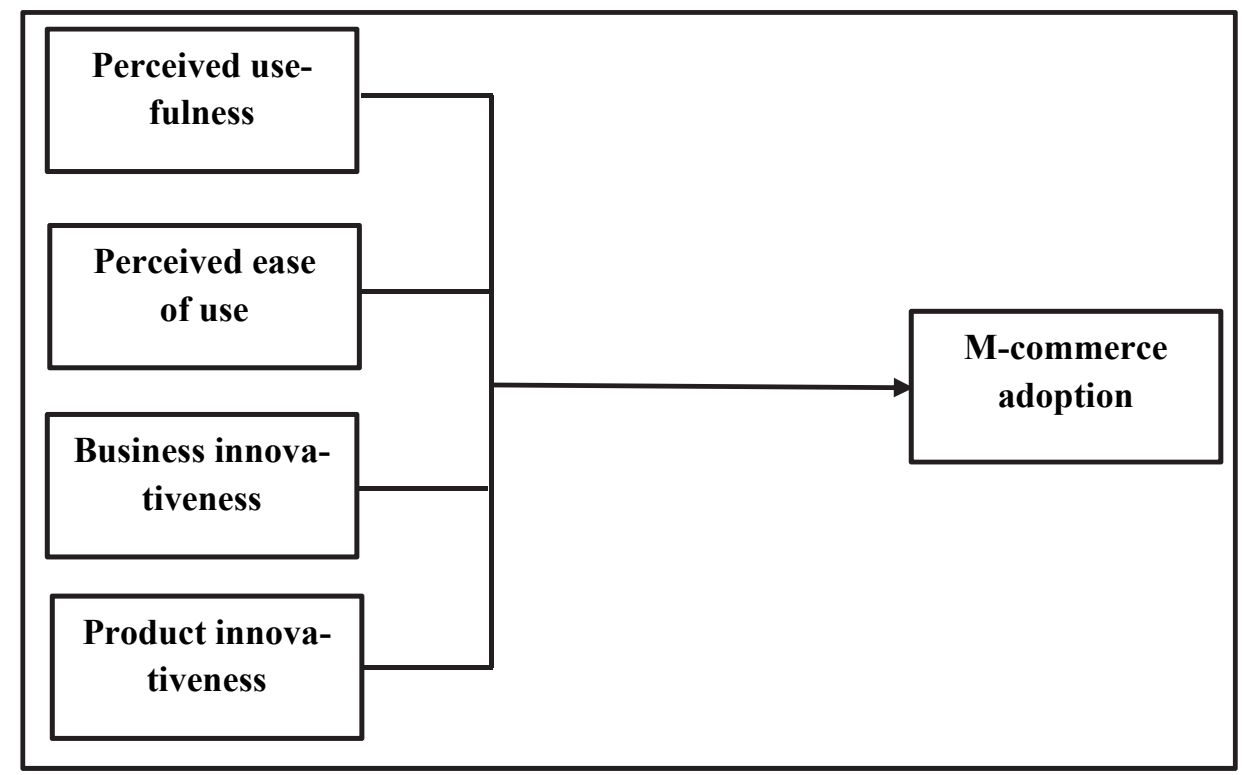

Fig. 1. Conceptual model

\section{Literature Review and theoretical background}

\subsection{Mobile Commerce Adoption}

M-Commerce is one of the emerging Information System (IS) based services. It is in the category of emarketing, e-learning, and other related e-commerce internet based technology trends. Because of its 
newness, series of definitions have been advanced but no consensus has been reached among scholars about how it should be defined. Moshin et al. (2003) for instance, asserted that a line of difference can hardly be drawn between m-commerce and e-commerce as the former is a representation or an extension of the latter and which indicates that it is a form of e-commerce being used through wireless devices (Varshney \& Vetter, 2002; Ashraf et al., 2016). Zhang et al. (2012) while corroborating Moshin et al. (2003) equally argued that m-commerce extends e-commerce as it affords business activities to be performed wirelessly using mobile devices. However, Feng et al. (2006) opined that m-commerce is a new invention which gives room for business opportunity and has different dimensions of mobility and broad reachability beyond e-commerce. Wei and Chong (2009) defined m-commerce as "any transaction, involving the transfer of ownership or rights to use goods and services, which is initiated and/or completed by using mobile access to computer-mediated networks with the help of mobile devices".

Despite lack of consensus about its definition, ample evidences are available about how the m-commerce positively influences the ways businesses are done across industries as it is increasingly becoming a significant strategy which organizations are employing to achieve improved performance (Chong, 2013). For instance, Thakur and Srivastava (2013) empirically proved that m-commerce affords organizations to offer personalized services to their customers while its ubiquities are assisting individual users to have instant access to usage without time and place restrictions (Chong, 2013). The prolific nature of $\mathrm{m}$-commerce across the industries in the $21^{\text {st }}$ has helped the practitioners generate over $\$ 1.3$ trillion revenue globally while the figure is projected to reach $\$ 1.8$ trillion in 2016 (Nassoura, 2013). Even though the advantages of m-commerce have been highlighted by many previous researchers, the rate of usage by individual users is still very low (Chong, 2013; Drossos \& Giaglis, 2006) while arguments still exist among scholars about specific factors that can be used to effectively predict its adoption. Predicting users' adoption behavior is essential for the growth of m-commerce, but empirical studies to validate this seem to be sparse (Chong, 2013) while most previous scholars have used various fragmented factors with a large of them employing TAM as the main model (e.g. Chong et al., 2011; Wei et al., 2009). Importantly, known scholars such as Venkatesh and Bala (2008), Yousafzai et al., (2010), Venkatesh et al. (2003) proved that TAM is robust and parsimonious as it is capable of explaining over $40 \%$ variance of users' attitude and behavior. In spite of its robustness, Barki (2007) for instance argued that since the main constructs of TAM are perceived usefulness and perceived ease of use, the model cannot fully guide m-commerce providers on what motivates users to either adopt or reject $\mathrm{m}$-commerce and if there are other precise factors that are pertinent to $\mathrm{m}$-commerce such as organizational innovativeness in our case. In this view, this study is extending original TAM by integrating organizational innovativeness and through which m-commerce can be predicted effectively.

\subsection{Perceived Usefulness (PU)}

Perceived Usefulness is one of core constructs of TAM. Basically, scholars from the field of information science (IS) and other related studies have generally acknowledged the importance of PU as it determines the acceptability or otherwise of new innovation like m-commerce (Amin et al., 2013; Wei et al., 2009). It is often seen as a subjective probability that when individuals use a system, their tasks would be accelerated (Jahangir \& Begum, 2008). Rouibah et al. (2011) refer to PU as the degree to which customers believe that adopting IT will yield important value for them. Amin et al. (2014) see $\mathrm{PU}$ as the general perception and evaluation done by mobile users with respect to the usability of $3 \mathrm{G}$ phones. Davis (1989, pg. 320) consideres PU as the "degree to which a person believes that using a particular system would enhance his or her job performance". Succinctly, this study defines PU as the benefits which users of mobile commerce may derive from the usage of the m-commerce. Such benefits or values may include facilitation of the process in locating a store, purchasing/selling of services and products, paying utility bills, executing banking transactions and even joining social networks (Khalifa \& Shen, 2008; Nassuora, 2013; Hsu \& Wang, 2011; Hanafizadeh et al., 2014; Yadav et al., 2016). Without these values, users will not be willing to adopt information system like m-commerce while the objectives of expending huge amount on m-commerce facilities may not be achieved by the service providers (Pikkarainen et al., 2004). This therefore indicates the users will rapidly adopt m-commerce 
if the service providers are able to provide superior benefits over other alternatives (Tsu Wei et al., 2009; Yadav et al., 2016) and this will further signifies the success and acceptance of the platform. Based on this, the following hypothesis is formulated

H1. Perceived usefulness has a positive and significant relationship on adoption of m-commerce

\subsection{Perceived Ease of use (PEU)}

PEU is another main construct of TAM which denotes the degree to which an individual perceives that using a new technology would not be hard. According to Davis (1989), perceived ease of use "is the degree to which a person believes that using a particular system would be free of effort". Amin et al., (2014) defined PEOU as the overall perception of users relating to the convenience of purchasing a mobile system via their mobile phone. In essence, a system may be deemed useful, but perceived to be difficult as such a system is not configured to 'ease' the task of the users. A system may also be regarded to be too complex if the resultant-benefits are being outweighed by the efforts applied in using the system. It therefore connotes that users would be wary of the efforts required to operate a new system like m-commerce and the more complexity involved in the process the more the users would avoid the system (Aboelmaged \& Gebba, 2013). A number of complexities such as small display screen, diffi-

culty in inputting data, internet connectivity, can constitute a barrier that may inhibit ease of browsing, information identification and performance of other transactions which could make individual users to have memorable experiences (Curran \& Meuter, 2005; Deb \& Lomo-David, 2014; Kleijnen et al., 2004; Porter \& Donthu, 2006, 2005; der Heijden et al., 2003). This is also in line with the arguments of Chong et al. (2010) as issue of designing an interface that is not interactive enough, especially for a mobilebased application can reduce the functionalities and accompany benefits of mobile system. Perceived ease of use has been confirmed to be instrumental in many studies such as electronic banking adoption (Salimon et al., 2016) internet usage (e.g., Abedalaziz et al., 2013; Teo et al., 2003), mobile instant messaging (e.g., Lauricella \& Kay, 2013), social networking (Bilgihan et al., 2016) and a host of others. Based on this, the following hypothesis is formulated

H2. Perceived ease of use has a positive and significant relationship to adopt m-commerce.

\subsection{Business innovativeness}

One of the first studies that conceptualized innovativeness is Rogers and Shoemaker (1971. p. 27), where innovativeness was referred to as "the degree to which an individual is relatively earlier in adopting new ideas than the average member of his social system". The main focus of this conceptualization was the apparent degree of innovativeness in behavioural patterns. Innovation literature has also demonstrated that business innovativeness is an important model for e-commerce adoption in firms, because even established firms are expected to continuously innovate to mitigate the threat of changes and competition resulting from the emerging IT environment (Lin \& Hsia, 2011). Firms' business innovativeness entails value-added activities in the production processes and presenting new goods and services using new business ideas (Dess \& Lumpkin, 1997; Knight, 1997). In addition, in the present competitive era, firms need to continuously create new products, discover new marketing approaches, and fashion out new production lines in order to improve their competitive performance and retain their customer base (Thakur et al., 2012). These strategies will allow firms to attain value addition for their customers, stimulate higher profitability and market share, and an improved organizational image. However, firms' good strategies alone are not enough for them to cope in the present dynamic business environment. It is expected that firms' business innovativeness should incorporate operational flexibility to survive within the present competitive market. However, the environment is taking a new dimension with the recent diversity in customer's behavioral patterns, their innovation attributes, and risk adoption levels (Lee et al., 2010). While previous studies have indicated how business innovativeness enhances firms' financial performance (e.g., Akgün, et al., 2014), assists in developing firm's core competencies and capabilities (Damanpour, et al., 2009), and improves firm's efficiency to detect and 
utilize available resources (Habtay, 2012), its influence on consumers' adoption of m-commerce has been largely ignored. A number of IS researchers have suggested that $\mathrm{m}$-commerce is one of the most important models that could easily get prompted by technological innovation, as it is an emerging platform for the expansion of access to transactions through mobile or handheld devices, and by operating wireless communication technologies (Lin, 2011). In this manner, business innovativeness is becoming more challenging as investing in such innovation not only requires a good understanding of the market diversities, but also a conscious recognition of the evolving user's preferences, which exerts a huge influence on firm's performance (Robinson et al., 2005; Belanche, et al., 2012). Thus, business innovativeness is posited to result in more positive attitude toward the adoption of m-commerce, leading to the following hypothesis:

H3. Business innovativeness has a significant and positive relationship with m-commerce adoption.

\subsection{Product innovativeness and m-commerce adoption}

Organizational success and sustained competitive advantage are some of the outcomes of organizational innovativeness. However, in spite of the continuous efforts in product design and marketing, most new products have recorded incessant failure (Srinivasan et al., 2009). While there has been several innovation studies, the literature mainly focused on organizational innovations in terms of product development and characteristics (Shmueli \& Koppius, 2010; Greenhalgh et al., 2004; Rogers, 1995; Wejnert, 2002). To date, much of the literature on mobile commerce adoption placed emphasis on customer innovativeness without much effort being directed towards firm innovative capacities. Whereas, product success is largely dependent on firms' ability to constantly stimulate innovative ideas, and compete favorably with customer-oriented products with stylish yet aptly functional contents (Gecevska et al., 2010). In spite of the imperative for firms to continually develop e-commerce delivery processes for competitive advantage (Patricio et al., 2008), we remain largely uninformed about the effect of firms' product innovativeness to aid consumer decision making to adopt mobile transactions.

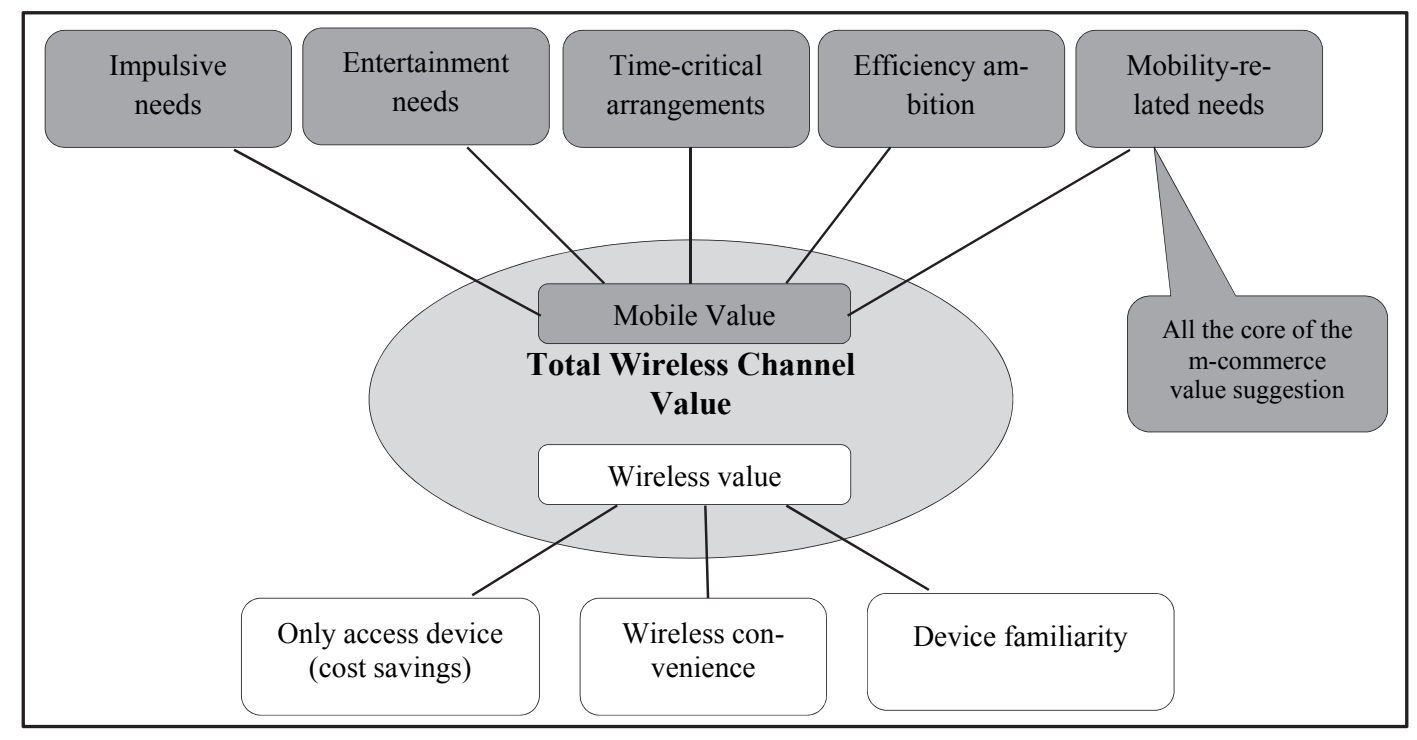

Fig. 2. Mobile commerce value elements (adapted from Anckar \& d'Incau, 2002)

Several innovativeness dimensions have also been examined to influence mobile transaction adoption. In particular, Yang (2005) demonstrated the direct effect of innovativeness on mobile commerce in the South East Asian countries, just like Leung and Antypas (2001) highlighted how product efficiency is improved in firms through mobile commerce by offering new avenues through which interaction with customers are perfected. Five factors for wireless services were listed by Anckar and d'Incau (2002) in their study on mobile commerce value creation, as illustrated in Fig. 2. 
Thus, in spontaneous needs, plans and decisions are not essential for $\mathrm{m}$-commerce adoption like purchase decisions that involve small amounts of money. The entertainment needs digital games and music. Time-criticality in mobile purchases requires the platform to satisfy consumers' time-critical needs with prompt and to-the-point interactions. In addition, as many customers nowadays prefer more effective ways of doing simple everyday activities, m-commerce efficiency needs and ambitions become a necessary time saver for purchases like mobile banking and travel reservations. According to Clarke (2008), mobility-related needs such as routing and tracking, location-based services and roadside services are not only of exclusive value in the entire mobile settings, but also constitute an essential part of mobile commerce value proposition. Since m-commerce offers a direct avenue to communicate with consumers via a mobile handheld, without space and time constraints, firms should utilize mobile commerce and communication as an innovative and interactive platform for business success. As innovation generates more marketing opportunities for firms, mobile media platforms should be utilized thanks to its superiority over the traditional communication (Chowdhury et al. 2010). Product innovativeness is likely to be associated with m-commerce adoption, resulting in the following hypothesis:

H4. Product innovativeness has a significant and positive relationship with m-commerce adoption.

\section{Methods}

\subsection{Sample and Procedure}

We employed mall intercept method to collect the data of the study from users of mobile commerce in a popular shopping mall in Lagos State, Nigeria using self-administered questionnaires. In using the mall intercept, the researcher first approached the potential respondents in order to ask for their consent of participation after which the questionnaires were administered. This method was used due to its veracity of having access to likely respondents within a short period of time, as it equally assists the researchers to have personal interactions with the respondents to screen the respondents and as well as stimulate their interest to participate in the research and its common use in marketing research (e.g. Grace \& O'cass, 2005; Maronick 1995; Prakash \& Venkatachalam, 2016). The questionnaire has two sections: The first section requires the respondents to provide answers to demographic information, while the second part asks some questions on the variables of the study. The questionnaire made use of a five-point Likert scale, which ranged from "strongly agree" to "strongly disagree".

All items measuring the latent constructs were adapted from previous studies that have validated the items. The items of mobile commerce adoption were adapted from Khalifa and Shen (2008), Luarn and Lin (2005), and Thakur and Srivastava (2013), perceived usefulness items were adapted from Khalifa and Shen (2008) and Wei et al. (2009), perceived ease of use items were selected from Amin et al. (2014), Lee et al., (2015) and Wei et al., (2009) while business innovativeness and product innovativeness items were also adapted from Kamaruddeen et al. (2012). Out of 430 questionnaires that were collected, 25 were discarded due to inappropriate fillings and which implies that only 405 questionnaires were used for the analysis indicating a response rate of 94 per cent.

Based on the demographic information, 57.2 per cent 42.8 percent were males and females respectively. With regards to their age range, majority of the respondents ( 36.5 per cent) were aged between 25 and 29 years old, 27.0 per cent of the respondents were aged between 30 and 34 years old and 15.8 per cent of the respondents were aged between 35 and 39 years old. This was followed by 10.8 per cent between 45 and 50 years old and 9.9 per cent between 40 and 44 years old. In terms of employment, 48.0 per cent of the respondents were private companies employees, 44.0 per cent were government employees, 8.0 per cent belongs to others. In terms of the marital status range, married respondents contributed largely to the sample (62 per cent), followed by single (34.6 per cent) and divorced respondents ( 3.4 per cent) (see Table 1). 
Table 1

Demographics of respondents

\begin{tabular}{lcc}
\hline & Frequency & $\%$ \\
\hline Gender & & \\
Male & 232 & 57.2 \\
Female & 173 & 42.8 \\
\hline Age & & \\
Age 20 and below 30 & 148 & 36.5 \\
Age between 30 and 34 & 109 & 27.0 \\
Age between 35 and 39 & 64 & 15.8 \\
Age between 40 and 44 & 40 & 9.9 \\
Age between 45 and 50 & 44 & 10.8 \\
\hline Employment Status & & \\
Private Employment & 195 & 48 \\
Government Employees & 179 & 44 \\
Others & 31 & 8 \\
\hline Marital Status & & \\
Married & 251 & 62 \\
Single & 140 & 34.6 \\
Divorced & 14 & 3.4 \\
\hline
\end{tabular}

\section{Data Analysis and Results}

\subsection{Assessment of measurement Model}

In order to analyze generated hypotheses, the researchers employed Partial least squares structural equation modelling (PLS-SEM). The PLS-SEM is regarded as a covariance based technique that contemporary academic researchers use in prediction or in the development of theory (Hair et al., 2017; Lowry \& Gaskin, 2014). In using the PLS-SEM, a two-step analytical approach is suggested by Anderson and Gerbing (1988). In the first-step, a measurement model was evaluated while in the secondstep, a structural model was equally analyzed.

For the purpose of analyzing the measurement model, factor analysis was performed in order to establish the fitness of the model. Hair et al. (2014) argue that reliability and validity are the two important criteria that are used to evaluate the theoretical soundness of a model. Measuring the reliability requires that the internal consistency reliability be established first. This criterion can be achieved through assessment of the values of composite reliability (CR) for each construct. Construct validity which is the second criterion that must be established before further analysis can be performed comprises convergent validity and discriminant validity (Hair et al., 2010). Convergent validity refers to the degree to which a measure positively correlates with another measures of the same variable (Hair et al., 2014). This therefore suggests that items of the same construct must share a degree of variance or converge. It has been suggested that for convergent validity to be ascertained, it is mandatory that the outer loadings of the items and as well as average variance extracted (AVE) must be considered (Hair et al., 2014). Hair et al. (2017) argue that the loadings and AVE must not be less than 0.50 and 0.70 respectively. Fig. 2 shows the result of the measurement model of the study. As shown in Table 2, all the values of loadings, and average variance explained (AVE) are greater than 0.50 while that of composite reliability and Cronbach alpha are higher than 0.70 . This therefore implies that the measurement model of this research is theoretically sound while the convergent validity has been established. Discriminant validity based on empirical standards refers to the degree to which a particular construct in the model is quite different from other constructs (Hair et al., 2014). This shows that the construct is unique by capturing the phenomenon which other constructs in the model do not capture. The discriminant validity can be ascertained by ensuring that AVE for each set of variables is greater than the squared correlations values of other constructs. Table 3 shows that this threshold has been achieved following Fornell and Larcker's (1981) approach. 


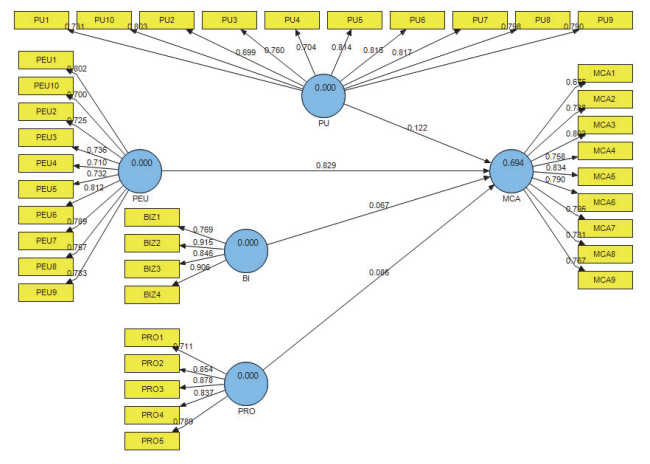

Table 2

Fig. 3. Measurement model

Factors Loading Significance

\begin{tabular}{|c|c|}
\hline Constructs and items & - \\
\hline Business innovativeness & AVE: $0.741 ; \alpha: 0.882 ;$ CR:0.919 \\
\hline $\mathrm{BIZ1}$ & 0.769 \\
\hline $\mathrm{BIZ2}$ & 0.915 \\
\hline $\mathrm{BIZ3}$ & 0.846 \\
\hline BIZ4 & 0.906 \\
\hline Perceived ease of use & AVE: $0.571 ; \alpha: 0.916 ;$ CR:0.930 \\
\hline PEU1 & 0.802 \\
\hline PEU2 & 0.725 \\
\hline PEU3 & 0.736 \\
\hline PEU4 & 0.710 \\
\hline PEU5 & 0.732 \\
\hline PEU6 & 0.812 \\
\hline PEU7 & 0.789 \\
\hline PEU8 & 0.757 \\
\hline PEU9 & 0.783 \\
\hline PEU10 & 0.700 \\
\hline Product innovativeness & AVE: 0.666; $\alpha: 0.874 ;$ CR:0.908 \\
\hline PRO1 & 0.711 \\
\hline $\mathrm{PRO} 2$ & 0.854 \\
\hline PRO3 & 0.878 \\
\hline PRO4 & 0.837 \\
\hline PRO5 & 0.789 \\
\hline Perceived usefulness & AVE: $0.600 ; \alpha: 0.925 ;$ CR:0.937 \\
\hline PU1 & 0.731 \\
\hline PU2 & 0.699 \\
\hline PU3 & 0.760 \\
\hline PU4 & 0.704 \\
\hline PU5 & 0.814 \\
\hline PU6 & 0.815 \\
\hline PU7 & 0.817 \\
\hline PU8 & 0.798 \\
\hline PU9 & 0.790 \\
\hline PU10 & 0.803 \\
\hline Mobile commerce adoption & AVE: $0.588 ; \alpha: 0.912 ;$ CR:0.928 \\
\hline MCA1 & 0.675 \\
\hline MCA2 & 0.738 \\
\hline MCA3 & 0.803 \\
\hline MCA4 & 0.758 \\
\hline MCA5 & 0.834 \\
\hline MCA6 & 0.790 \\
\hline MCA7 & 0.795 \\
\hline MCA8 & 0.731 \\
\hline
\end{tabular}

Table 3

Results of construct reliability and validity

\begin{tabular}{llccccc}
\hline & & $\mathbf{1}$ & $\mathbf{2}$ & $\mathbf{3}$ & $\mathbf{4}$ & $\mathbf{5}$ \\
\hline 1 & Business innovativeness & $\mathbf{0 . 8 6}$ & & & & \\
2 & Mobile commerce adoption & 0.553 & $\mathbf{0 . 7 6 7}$ & & & \\
3 & Perceived ease of use & 0.603 & 0.527 & $\mathbf{0 . 7 5 6}$ & & \\
4 & Product innovativeness & 0.705 & 0.575 & 0.629 & $\mathbf{0 . 8 1 6}$ & \\
5 & Perceived usefulness & 0.610 & 0.632 & 0.693 & 0.652 & $\mathbf{0 . 7 7}$ \\
\hline
\end{tabular}


Diagonal elements are the square roots of the AVE of each construct. For adequate discriminant validity, diagonal elements should be greater than the corresponding off-diagonal elements.

\subsection{Assessment of Structural Model}

The assessment of structural model is required as it shows the relationship between latent constructs that the researchers hypothesized. In order to ascertain the significant value of loadings, as well as that of path coefficients, a bootstrapping of 5000 subsamples was performed (Hair et al., 2017). Fig 4, and Table 4 reveal the result of the structural model.

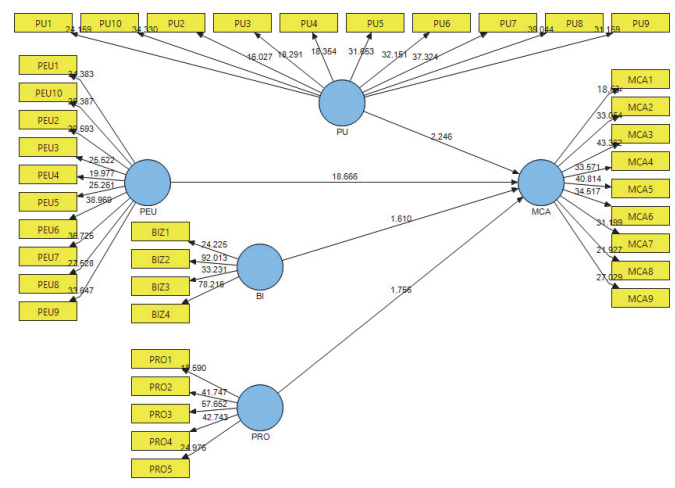

Fig. 4. Structural Model

\section{Table 4}

Testing results of main effect structural equation model

\begin{tabular}{lccccc}
\hline Hvpotheses & Beta & SE & t- value & p-value & Decision \\
\hline Business innovativeness & 0.067 & 0.045 & 1.610 & 0.07 & Supported \\
Perceived ease of use & 0.829 & 0.047 & 18.666 & 0.00 & Supported \\
Product innovativeness & 0.086 & 0.049 & 1.756 & 0.04 & Supported \\
Perceived usefulness & 0.122 & 0.055 & 2.246 & 0.01 & Supported \\
\hline
\end{tabular}

Dependent variable: Mobile commerce adoption

Table 4 shows the PLS outputs of the structural model as it is equally depicted in Fig. 2 which reveals the path coefficients, and coefficient determinants $\left(\mathrm{R}^{2}\right)$ of each construct. As shown in the table, perceived usefulness was significantly related to mobile commerce adoption $(\beta=0.122$, t.2.246) thereby supporting H1. Perceived ease of use was also a significant predictor of mobile commerce adoption $(\beta$ $=0.829, t .18 .666)$, likewise business innovativeness $(\beta=0.067, t .1 .610)$, and product innovativeness $(\beta=0.086, t .1 .756)$, making $\mathrm{H} 2, \mathrm{H} 3$, and $\mathrm{H} 4$ to be supported.

\subsection{Predictive Relevance of the model (Q2)}

Hair et al. (2014) suggest additionally step to ascertain the theoretical soundness of a model by using the StoneGeisser's Q2 measure (Geisser, 1974; Stone, 1974). The Q2 value assists the researcher to establish the predictive power of the model apart from the coefficient of determination $\left(\mathrm{R}^{2}\right)$ as it shows the degree to which the values observed are recaptured by the structural model and its approximating yardsticks' (Luqman et al., 2016). The value of $Q^{2}$ in the structural model that is higher than zero for a given reflective-construct is an indication that the model's path has predictive relevance required for a given endogenous variable (Hair et al., 2014). For researchers to establish the predictive relevance, blindfolding procedure is required employing $\mathrm{D}=7$ omission distance (Hair, et al., 2012) and this will assist the researcher to obtain the $\mathrm{Q}^{2}$ value which is based on the 'cross-validated redundancy' that is integrated in the PLS-SEM (Hair et al., 2014). As shown in Table 5, the Q2 value of 0.399 is higher than zero indicating that the model in this study has required predictive relevance. 
Table 5

Predictive Relevance of the Endogenous Construct

\begin{tabular}{lcc}
\hline Endogenous constructs & $\boldsymbol{R}^{\mathbf{2}}$ & $\boldsymbol{Q}^{\mathbf{2}}$ \\
\hline MCA & 0.694 & 0.399 \\
\hline
\end{tabular}

\subsection{Effect Size $\left(F^{2}\right)$}

The purpose of effect size $\left(\mathrm{F}^{2}\right)$ is to assess the contribution of exogenous construct to the value of coefficient determinant (R2) of the endogenous construct. As shown in Table 6, perceived ease of use and perceived usefulness show large to small effect size.

Table 6

Effect Size

\begin{tabular}{lcc}
\hline & \multicolumn{2}{c}{ MCA (dependent variable) } \\
\hline Business innovativeness & $\boldsymbol{f}^{2}$ & Effect size \\
Perceived ease of use & 0.003 & None \\
Product innovativeness & 0.77 & Large \\
Perceived usefulness & 0.01 & None \\
\hline
\end{tabular}

\section{Discussion}

This study employs TAM and organizational innovativeness to explain adoption of mobile commerce in a developing country, Nigeria. In this instance, TAM was extended by incorporating business innovativeness and product innovativeness with perceived usefulness and perceived ease of use. The study hypothesizes four relationships. The First hypothesis (H1) which states a positive relationship between perceived usefulness and mobile commerce adoption was supported. Previous studies have equally proved that perceived usefulness is an important factor that can accelerate the rate of adoption of IS/IT such as mobile commerce (Wei et al., 2009; Yadav et al., 2016), e-commerce (Guriting \& Ndubisi, 2006; Jahangir \& Begum, 2008) and e-banking (Aboelmaged \& Gebba, 2013; Tan et al., 2010). These findings have shown that the adoption of mobile technology is majorly anchored on the perception of usefulness by the consumers as the consumers would only increase the rate of usage if, for instance, they can retrieve required information with urgency, perform the transaction seamlessly and achieve their daily and other mobile commerce transaction objectives (Wei et al., 2009).

The second hypothesis (H2) which states a positive relationship between perceived ease of use and mobile commerce adoption was also accepted. A number of scholars have equally reported that the easiness that is associated with IS/IT based services such as social networking (Wamba, et al., 2017), e-government (Carter et al., 2016; Susanto \& Aljoza, 2015), e-insurance (Leeet al., 2015) and mobile banking (Safeena et al., 2011) is a core determinant of adoption of these latest technology trends. The essence of these findings indicate that the absence of face-to-face interaction that is common in an internet enabled services platforms such as mobile commerce requires such platform to be easily used with regards to user friendliness as this will reduce the difficulty that may be associated with the usage of the services (Chong et al., 2010). This has been initially reiterated by Pikarrainen et al. (2004) that a system that is regarded to be easily learned and used is likely to be accepted than otherwise.

The third hypothesis (H3) which states a positive relationship between business innovativeness and mobile commerce adoption was also accepted. This relationship has been previously confirmed by a number of studies indicating that innovativeness in all its ramification can improve business performance, such as adoption of mobile commerce (Aragon-Correa et al., 2007; Erdem et al., 2011; GarciaMorales et al., 2008; Noruzy et al., 2013; Samad, 2012; Y1ldız et al., 2014). The finding indicates that 
continuous changes in customer needs coupled with a competitive business environment require business organizations to be innovative in their approaches through new methods and systems (Yildiz et al., 2014). Experience has shown that any organization that resists innovation will likely fizzle out since its performance will continue to decrease while businesses that are innovative will improve in performance (high rate of mobile commerce adoption).

The fourth hypothesis (H4) states a positive relationship between product innovativeness and mobile commerce adoption was supported. Product innovativeness which indicates novelty, perceived newness, uniqueness or originality of products has equally been found to improve performance in different studies (e.g., Henard \& Szymanski, 2001). The result points to the fact that mobile commerce companies that can introduce new attributes which users perceived to be unique, perhaps with functionality, ease of use and usability will attract more patronage thereby increase the rate of adoption of new innovation such as mobile commerce. In line with the argument of Anckar and d'Incau (2002) embedding mobile commerce wireless value that will take care of impulsive needs, saves cost and gives convenience will make the rate of adoption to be increased.

\section{Conclusion}

Mobile commerce is one of the current waves of information technology. However, for the purpose of coping with the high velocity of changes that are taking place in the contemporary global competitive market, and especially in the mobile commerce industry, it is highly important that mobile commerce providers should place priority on ensuring that the platform is reconfigured and strengthened for the purpose of serving the current users effectively and to attract a large number of potential users. For instance, to increase the rate of adoption, our findings regarding the perceived usefulness with respect to the benefits of mobile commerce; perceived ease of use concerning easiness that surrounds the usage; business innovativeness and product innovativeness regarding the incorporation of wireless value (cost savings access device, wireless convenience, device family familiarity) and mobile value (impulsive needs, entertainment needs, time-critical arrangements, efficiency ambition and mobility related needs) (see Fig. 2) should be seriously considered as these will perform a critical role in the transformation of m-commerce.

The findings of this research with respect to PU and PEU therefore indicate that while designing $\mathrm{m}$ commerce platforms, it is essential that the designers ensure that the platforms are useful, and easily used. This therefore points to the fact that $\mathrm{m}$-commerce designers should provide improved and variety of services, design the platform to meet the needs of the users while the users face less physical and mental rigor when using the platform. The usefulness of mobile commerce against any other platform such as e-commerce is that users can also use the platform to perform other internet based functions such as reading news, sending email, or watching videos apart from the core uses of the platform. Configuring the platform to comply with this ensures that the users are equally attracted largely. Aside, the easiness that the designers may embed with the platform may ease the difficulty that will likely be associated with the physical characteristics of mobile devices with respect to tiny display screen, strain in inputting data and others that can inhibit m-commerce adoption. In particular, it is important that a reminder be sent to mobile commerce managers and practitioners that innovation as discussed in this study would not just arrive overnight but comes through insight that inspires change which can be initiated through product or business process (Wong, 2012). In this regard, it is imperative for mobile commerce providers to be flexible by ensuring that their mind is opened while permitting their product and process engineers to think, dream, and initiate new ideas as long as organization's resources allow as this is the greatest way to encourage innovation that would improve the rate of adoption of mobile commerce.

This study extended TAM by adding product business innovativeness and product innovativeness which previous researchers have largely ignored. By adding these variables, the simplicity of TAM has 
been retained while its parsimony is equally improved. By the integration of organizational innovations concept with TAM, this study presents a considerable improvement in predictive ability of the proposed model. Asides, this study used PLS-SEM to predict and understand important constructs which can improve the m-commerce adoption.

\section{Limitation of the study}

This research has a number of limitations despite that it is expected to contribute to the body of knowledge and practice in the mobile commerce industry in Nigeria. First, the study is quantitative and cross-sectional nature in nature; it only captured and analyzed a limited number of factors that can influence mobile commerce adoption in a developing country. In this regard, a qualitative and longitudinal research should be done to have a broad comprehension and perspective of other factors that are not covered in this study. In line with the recommendations of previous researchers, coming studies can incorporate factors such as security-privacy, consumer self-efficacy, perceived risk and trust (Chong, 2013; Faqih \& Jaradat, 2015) for the purpose of understanding and predicting adoption of mobile commerce effectively. Second, this study was conducted in a developing country where the level of technology usage and organizational innovation is still coming up. In this regard, the generalization of our findings should be applied with caution, especially to other developed and developing countries. In this regard, further studies may be conducted in other developing countries based on multicountries comparison using the model of this study. If this is done, the veracity of our model can further be ascertained.

\section{References}

Abedalaziz, N., Jamaluddin, S., \& Chin, H. L. (2013). Measuring attitudes toward computer and internet usage among postgraduate students in Malaysia. The Turkish Online Journal of Educational Technology, 12 (2), 200-214.

Aboelmaged, M. G., \& Gebba, T. R. (2013). Mobile Banking Adoption: An Examination of Technology Acceptance Model and Theory of Planned Behavior. International Journal of Business Research and Development, 2 (1), 35-50.

Akgün, A. E., Ince, H., Imamoglu, S. Z., Keskin, H., \& Kocoglu, İ. (2014). The mediator role of learning capability and business innovativeness between total quality management and financial performance. International Journal of Production Research, 52(3), 888-901.

Alalwan, A. A., Dwivedi, Y., Rana, N. P., \& Williams, M. D. (2016). Consumer adoption of mobile banking in Jordan: examining the role of usefulness, ease of use, perceived risk and self-efficacy. Journal of Enterprise Information Management, 29 (1), 118-139.

Amin, M., Rezaei, S., \& Abolghasemi, M. (2014). User satisfaction with mobile websites: the impact of perceived usefulness (PU), perceived ease of use (PEOU) and trust, Nankai Business Review International, 5 (3), 258-274.

Anckar, B., \& D'incau, D. (2002). Value creation in mobile commerce: Findings from a consumer survey. Journal of Information Technology Theory and Application,4(43), 43-64.

Anderson, J. C., \& Gerbing, D. W. (1988). Structural equation modeling in practice: A review and recommended two-step approach. Psychological Bulletin, 103(3), 411-423.

Aragon-Correa, J.A., Garcia-Morales, V.J. \& Cordon-Poza, E. (2007). Leadership and orgaizational learning's role on innovation and performance: Lesson from Spain. Industrial Marketing Management, 36 (1), 349-359.

Ashraf, A. R., Thongpapanl, N., Menguc, B., \& Northey, G. (2016). The role of m-commerce readiness in emerging and developed markets. Journal of International Marketing, 25 (2), 25-51.

Barki, H. (2007). Quo vadis TAM? Journal of the AIS, 8 (1), 211-218.

Bhatti, T. (2015), Exploring factors influencing the adoption of mobile commerce. The Journal of Internet Banking and Commerce, 12 (3), 1-13. 
Bilgihan, A., Barreda, A., Okumus, F., and Nusair, K. (2016). Consumer perception of knowledgesharing in travel-related Online Social Networks. Tourism Management, 52 (1), 287-296.

Carter, L., Weerakkody, V., Phillips, B., \& Dwivedi, Y. K. (2016). Citizen adoption of e-government services: Exploring citizen perceptions of online services in the United States and United Kingdom. Information Systems Management, 33 (2), 124-140.

Chong, A. Y. L. (2013). A two-staged SEM-neural network approach for understanding and predicting the determinants of m-commerce adoption. Expert Systems with Applications, 40 (4), 1240-1247.

Chong, A. Y. L., Chan, F. T. S., \& Ooi, K. B. (2011). Predicting consumer decisions to adopt Mobile Commerce: Cross country empirical examination between China and Malaysia. Decision Support Systems, 53(1), 34-43.

Chowdhury, H. K., Parvin, N., Weitenberner, C., and Becker, M. (2010). Consumer attitude toward mobile advertising in an emerging market: An empirical study. Marketing,12(2), 206-216.

Clarke III, I. (2008). Emerging value propositions for m-commerce, Journal of Business Strategies, 25(2), 41-57.

Curran, J. M., \& Meuter, M. L. (2005). Self-service technology adoption: comparing three technologies, Journal of Services Marketing, 19 (2), 103-113.

Damanpour, F., Walker, R. M., \& Avellaneda, C. N. (2009). Combinative effects of innovation types and organizational performance: A longitudinal study of service organizations. Journal of management studies, 46 (4), 650-675.

Davis, F. D. (1989). Perceived usefulness, perceived ease of use and user acceptance of information technology. MIS Quarterly, 13(3), 319-340.

der Heijden, H., Verhagen, T. \& Creemers, M. (2003). Understanding online purchase intentions: contributions from technology and trust perspectives. European Journal of Information Systems, 12 (1), 41-48.

Dess, G. G., Lumpkin, G. T., \& Covin, J. G. (1997). Entrepreneurial strategy making and firm performance: Tests of contingency and configurational models. Strategic Management Journal, 18(9), 677-695.

Drossos, D., \& Giaglis, G. M. (2006). Mobile advertising effectiveness: An exploratory study. In IEEE international conference on mobile business. Copenhagen, 26-27th June.

Erdem, B., Gökdeniz, A. \& Met, Ö. (2011). The relationship between innovation and business performance: A case study of five star hotels' managements in Antalya. Faculty of Economy and Administrative Sciences Journal, 26 (2), 77-112.

Faqih, K. M., \& Jaradat, M. I. R. M. (2015). Assessing the moderating effect of gender differences and individualism-collectivism at individual-level on the adoption of mobile commerce technology: TAM3 perspective. Journal of Retailing and Consumer Services, 22(1), 37-52.

Feng, H., Hoegler, T. \& Stucky, W. (2006). Exploring the critical success factors for mobile commerce. Proceedings of the International Conference on Mobile Business (ICMB'06), Copenhagen, Denmark.

Fornell, C., \& Larcker, D. F. (1981). Evaluating structural equation models with unobservable and measurement error. Journal of Marketing Research, 18(1), 39- 50.

Garcia-Morales, J.V., Llorens-Montes, F.J. \& Verdu-Jover, A.J. (2008). The effects of transformational leadership on organizational performance through knowledge and innovation. British Journal of Management, 19(1), 299-319.

Gecevska, V., Chiabert, P., Anisic, Z., Lombardi, F., \& Cus, F. (2010). Product lifecycle management through innovative and competitive business environment. Journal of Industrial Engineering and Management, 3(2), 323-336.

Grace, D., \& O'cass, A. (2005). Examining the effects of service brand communications on brand evaluation. Journal of Product \& Brand Management, 14(2), 106-116.

Greenhalgh, T., Robert, G., Macfarlane, F., Bate, P., \& Kyriakidou, O. (2004). Diffusion of innovations in service organizations: systematic review and recommendations. Milbank Quarterly, 82(4), 581629. 
Guriting, P. \& Ndubisi, A.O. (2006). Borneo online banking: evaluating customer perceptions and behavioral intention. Management Research News, 29(1/2), 6-15.

Hair, J. F., Anderson, R. E., Babin, B. J., \& Black, W. C. (2010). Multivariate data analysis: A global perspective (Vol. 7). Upper Saddle River, NJ: Pearson.

Hair, J. F., Sarstedt, M., Ringle, C. M., and Mena, J. A. (2012). An assessment of the use of partial least squares structural equation modeling in marketing research. Journal of the Academy of Marketing Science, 40(3), 414-433.

Hair Jr, J., Sarstedt, M., Hopkins, L., \& G. Kuppelwieser, V. (2014). Partial least squares structural equation modeling (PLS-SEM) An emerging tool in business research. European Business Review, 26(2), 106-121.

Hair Jr, J., Hult, F., \& GTM, R. C., \& Sarstedt, M.(2017). A primer on partial least squares structural equation modeling. (PLS-SEM)(2nd edition ed.) Sage Publications, Thousand Oaks.

Hanafizadeh, A., Behboudi, M., Koshksaray, A.A. \& Tabar, M.J.S. (2014). Mobile-banking adoption by Iranian bank clients. Telematics and Informatics, 31(1), 62-78.

Habtay, S. R. (2012). A firm-level analysis on the relative difference between technology-driven and market-driven disruptive business model innovations. Creativity and Innovation Management, 21 (3), 290-303.

Henard, D. H., \& Szymanski, D. M. (2001). Why some new products are more successful than others. Journal of marketing Research, 38(3), 362-375.

Hsu, C.L. \& Wang, C.F. (2011). Investigating customer adoption behaviors in mobile financial services. International Journal of Mobile Communications, 9(5), 477-494.

Jahangir, N., \& Begum, N. (2008). The role of perceived usefulness, perceived ease of use, security and privacy, and customer attitude to engender customer adaptation in the context of electronic banking. African Journal of Business Management, 2 (2), 32-40.

Kamaruddeen, A. M., Yusof, N. A., Said, I., \& Pakir, A. H. K. (2012). Organizational factors and innovativeness of housing developers. American Journal of Applied Sciences, 9 (12), 1953-1966.

Kam-Sing Wong, S. (2012). The influence of green product competitiveness on the success of green product innovation: Empirical evidence from the Chinese electrical and electronics industry. European Journal of Innovation Management, 15(4), 468-490.

Khalifa, M., \& Ning Shen, K. (2008). Explaining the adoption of transactional B2C mobile commerce. Journal of Enterprise Information Management, 21(2), 110-124.

Kleijnen, M., Wetzels, M., \& Ruyter, K. D. (2004). Consumer acceptance of wireless finance. Journal of Financial Services Marketing, 8(3), 206-217.

Knight, G. (1997). Cross-cultural reliability and validity of a scale to measure firm entrepreneurial orientation. Journal of Business Venturing, 12(1), 213-225.

Lauricella, S., \& Kay, R. (2013). Exploring the use of text and instant messaging in higher education classrooms. Research in Learning Technology, 25(1), 1-12.

Lam, S. Y., Chiang, J., \& Parasuraman, A. (2008). The effects of the dimensions of technology readiness on technology acceptance: An empirical analysis. Journal of Interactive Marketing, 22(4), 1939.

Lee, V. H., Lam, S. Y., Ooi, K. B., \& Safa, M. S. (2010). Structural analysis of TQM and its impact on customer satisfaction and innovation. International Journal of Modelling in Operations Management, 1(2), 157-179.

Lee, C. Y., Tsao, C. H., \& Chang, W. C. (2015). The relationship between attitude toward using and customer satisfaction with mobile application services: an empirical study from the life insurance industry. Journal of Enterprise Information Management, 28(5), 680-697.

Leung, K., \& Antypas, J. (2001). Improving returns on m-commerce investments. The Journal of Business Strategy, 22(5), 12-13.

Liao, C. H., Tsou, C. W., \& Huang, M. F. (2007). Factors influencing the usage of 3 G mobile services in Taiwan. Online Information Review, 31(6), 759-774. 
Lin, H. F. (2011). An empirical investigation of mobile banking adoption: The effect of innovation attributes and knowledge-based trust. International Journal of Information Management, 31(3), 252-260.

Lin, L. M., \& Hsia, T. L. (2011). Core capabilities for practitioners in achieving e-business innovation. Computers in Human Behavior, 27(5), 1884-1891.

Lowry, P. B., \& Gaskin, J. (2014). Partial least squares (PLS) structural equation modeling (SEM) for building and testing behavioral causal theory: When to choose it and how to use it. IEEE Transactions on Professional Communication, 57(2), 123-146.

Luarn, P., \& Lin, H. H. (2005). Toward an understanding of the behavioral intention to use mobile banking. Computers in Human Behavior, 21(6), 873-891.

Luqman, A., Razak, R. C., Ismail, M., \& Alwi, M. A. M. (2016). Predicting continuance intention in mobile commerce usage activities: The Effects of Innovation Attributes. In 8th International Conference on Humanities and Social Sciences held on (pp. 1-29).

Maronick, T. J. (1995). An empirical investigation of consumer perceptions of "made in USA" claims. International Marketing Review, 12(3), 15-30.

Moshin, M., Mudtadir, R., \& Ishaq, A.F.M. (2003). Mobile commerce - the emerging frontier: exploring the prospects, application and barriers to adoption in Pakistan. International Workshop on Frontiers of IT, Islamabad.

Nassuora, A. B. (2013). Understanding factors affecting the adoption of m-commerce by consumers. Journal of Applied Sciences, 13(6), 913.

Noruzy, A., Dalfard, V. M., Azhdari, B., Nazari-Shirkouhi, S., \& Rezazadeh, A. (2013). Relations between transformational leadership, organizational learning, knowledge management, organizational innovation, and organizational performance: an empirical investigation of manufacturing firms. The International Journal of Advanced Manufacturing Technology, 64(1), 1073-1085.

Nysveen, H., Pedersen, P. E., \& Thorbjørnsen, H. (2005). Explaining intention to use mobile chat services: moderating effects of gender. Journal of Consumer Marketing, 22(5), 247-256.

Osakwe, C. N., \& Okeke, T. C. (2016). Facilitating mCommerce growth in Nigeria through mMoney usage: A preliminary analysis. IJIKM, 11 .

Pikkarainen, T., Pikkarainen, K., Karjaluoto, H. \& Pahnila, S. (2004). Consumer acceptance of online banking: an extension of the technology acceptance model. Internet Research, 14 (3), 224-35.

Porter, E. \& Donthu, N. (2006). Using the technology acceptance model to explain how attitudes determine internet usage. Journal of Business Research, 59 (9) 999-1007.

Prakash, K., \& Venkatachalam, S. M. (2016). Consumer perception towards private label brands. PARIPEX-Indian Journal of Research, 5(7).

Rana, N.P., Dwivedi, Y.K. \& Williams, M.D. (2013). Evaluating alternative theoretical models for examining citizen centric adoption of e-government. Transforming Government: People, Process and Policy, 7 (1), 27-49.

Riquelme, H.E. \& Rios, R.E. (2010). The moderating effect of gender in the adoption of mobile banking, International Journal of Bank Marketing, 28(5), 328-341

Robinson, L., Marshall, G.W. \& Stamps, M.B. (2005). Sales force use of technology: Antecedents to technology acceptance. Journal of Business Research, 58(12), 1623-31.

Rogers Everett, M. (1995). Diffusion of Innovations. New York, 12.

Rouibah, K., Abbas, H., \& Rouibah, S. (2011). Factors affecting camera mobile phone adoption before e-shopping in the Arab world. Technology in Society, 33(3), 271-283.

Safeena, R., Hundewale, N., \& Kamani, A. (2011). Customer's adoption of mobile-commerce a study on emerging economy. International Journal of e-Education, e-Business, e-Management and eLearning, 1 (3), 228-233.

Samad, S. (2012). The influence of innovation and transformational leadership on organizational performance, Procedia-Social and Behavioral Sciences. 57(1) 486-493.

Shareef, M.A., Kumar, V., Kumar, U. \& Dwivedi, Y. (2014). Factors affecting citizen adoption of transactional electronic government. Journal of Enterprise Information Management, 27(4), 385401. 
Shmueli, G., \& Koppius, O. R. (2010). Predictive analytics in information systems research. MIS Quarterly, 35(3), 553-572.

Srinivasan, S., Pauwels, K., Silva-Risso, J., \& Hanssens, D. M. (2009). Product innovations, advertising, and stock returns. Journal of Marketing, 73(1), 24-43.

Susanto, T. D., \& Aljoza, M. (2015). Individual acceptance of e-Government services in a developing country: Dimensions of perceived usefulness and perceived ease of use and the importance of trust and social influence. Procedia Computer Science, 72 (1), 622-629.

Tan, G. W. H., Chong, C. K., Ooi, K. B., \& Chong, A. Y. L. (2010). The adoption of online banking in Malaysia: an empirical analysis. International Journal of Business and Management Science, 3(2),169-193.

Teo, T. S. H., \& Pok, S. H. (2003). Adoption of WAP-enabled mobile phones among Internet users. The International Journal of Management Science, 31(6), 483-498.

Thakur, R. \& Srivastav, M. (2013). Customer usage intention of mobile commerce in India: An empirical investigation. Journal of Indian Business Research, 5(1), 52-72.

Thakur, R., Hsu, S. H., \& Fontenot, G. (2012). Innovation in healthcare: Issues and future trends. Journal of Business Research, 65 (4), 562-569.

Tsu Wei, T., Marthandan, G., Yee-Loong Chong, A., Ooi, K. B., \& Arumugam, S. (2009). What drives Malaysian m-commerce adoption? An empirical analysis. Industrial Management \& Data Systems, 109(3), 370-388.

United Nations (2002). E-Commerce and Development Report 2002, available at: www.r0.unctad. org/ecommerce/ecommerce_en/edr02_en.htm (accessed May 25).

Varshney, U. \& Vetter, R. (2002). Mobile commerce: framework, applications and networking support. Mobile Networks and Applications, 7(1), 185-98.

Venkatesh, V., Morris, M., Davis, G., \& Davis, F. (2003). User acceptance of information technology: Toward a unified view. MIS Quarterly, 27(3), 425-478.

Venkatesh, V., \& Bala, H. (2008). Technology acceptance model 3 and a research agenda on interventions. Decision Sciences, 39(2), 273-315.

Venkatesh, V., Morris, M., Davis, G., \& Davis, F. (2003). User acceptance of information technology: Toward a unified view. MIS Quarterly, 27(3), 425-478.

Wei, T. T., \& Chong, A. Y. (2009). What drives Malaysian m-commerce adoption ? An empirical analysis. Industrial Management \& Data Systems, 109(3), 370-388.

Wejnert, B. (2002). Integrating models of diffusion of innovations: A conceptual framework. Annual Review of Sociology, 28(1), 297-326.

Wong, C.C. and Hiew, P.L. (2005). Diffusion of mobile entertainment in Malaysia: drivers and barriers. Enformatika, 5(1), 263-6.

Yadav, R., Sharma, S. K., \& Tarhini, A. (2016). A multi-analytical approach to understand and predict the mobile commerce adoption. Journal of Enterprise Information Management, 29(2), 222-237.

Yang, K. C. (2005). Exploring factors affecting the adoption of mobile commerce in Singapore. Telematics and Informatics, 22(3), 257-277.

Yıldız, S., Baștürk, F., \& Boz, İ. T. (2014). The effect of leadership and innovativeness on business performance. Procedia-Social and Behavioral Sciences, 150(1), 785-793.

Yousafzai, S. Y., Foxall, G. R., \& Pallister, J. G. (2010). Explaining internet banking behavior: Theory of reasoned action, theory of planned behavior, or technology acceptance Model. Journal of Applied Social Psychology, 40(5), 1172-1202.

Zhang, L., Zhu, J., \& Liu, Q. (2012). A meta-analysis of mobile commerce adoption and the moderating effect of culture. Computers in Human Behavior, 28(5), 1902- 1911.

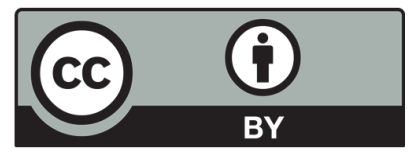

(C) 2017 by the authors; licensee Growing Science, Canada. This is an open access article distributed under the terms and conditions of the Creative Commons Attribution (CC-BY) license (http://creativecommons.org/licenses/by/4.0/). 